\title{
Use of corticosteroid therapy on the modulation of uterine inflammatory response in mares after artificial insemination with frozen semen
}

\author{
Frederico Ozanam Papa, José Antonio Dell'aqua Junior, Marco Antonio Alvarenga, Cely Marini Melo, Fabíola Soares Zahn \\ and Maria Denise Lopes
}

Department of Animal Reproduction and Veterinary Radiology, UNESP, Botucatu-SP, Brazil

\begin{abstract}
Summary
In order to modulate uterine inflammatory response and evaluate the effect of corticosteroid therapy on fertility, 90 cycles of 45 mares were used for artificial insemination with frozen semen, using three different protocols: $\mathrm{G} 1$ - inseminated with frozen semen $\left(800 \times 10^{6}\right.$ viable spermatozoa pre-freezing $)+20 \mathrm{~mL}$ of seminal plasma; G2 - inseminated with frozen semen $\left(800 \times 10^{6}\right.$ viable spermatozoa pre-freezing $)$ + corticosteroid therapy; G3 - inseminated with frozen semen $\left(800 \times 10^{6}\right.$ viable spermatozoa pre-freezing $)+20 \mathrm{~mL}$ of seminal plasma + corticosteroid therapy. Corticosteroid therapy consisted on one administration of prednisolone acetate $\left(0.1 \mathrm{mg} / \mathrm{Kg}\right.$ - Predef $\left.{ }^{\circledR}\right)$ when mares presented $35 \mathrm{~mm}$ follicles and uterine edema, concomitantly with the unique dose of hCG (human chorionic gonadotropin), then repeated each 12 hours until ovulation. On first fertility trial, with normal mares, there was no difference between control and treated groups ( $>0.05$ ), using seminal plasma associated with corticosteroid therapy (40 vs. $38 \%$, respectively) or corticosteroid therapy alone (40 vs. $45 \%$, respectively). The second fertility trial, performed with mares with previous history of post-insemination endometritis, demonstrated a significant increase of pregnancy rate when mares were submitted to corticosteroid therapy $(0.0 \mathrm{vs.} 64.5 \%$, respectively; $p<0.05)$. Corticosteroid therapy was shown to be safe, with no physical or reproductive alterations on treated mares, demonstrating to be an adequate option to those animals with history of post-breeding or post-insemination endometritis. Further clinical research is necessary to confirm these results and contribute to the establishment of preventive therapy for cases of post-insemination endometritis.
\end{abstract}

Keywords: Equine, corticosteroid, seminal plasma, frozen semen, fertility, reproduction

Einfluss einer Kortikosteroidtherapie auf die Regulierung der uterinen Entzündungsreaktion bei Stuten nach künstlicher Besamung mit Gefriersperma

Um die uterine Entzündungsreaktion zu beeinflussen und den Effekt einer Kortikosteroidtherapie auf die Fertilität zu bewerten, wurden 90 Zyklen von 45 Stuten für die künstliche Besamung mit Gefriersperma nach drei verschiedenen Schemata genutzt: G1 - besamt mit Gefriersperma $\left(800 \times 10^{6}\right.$ lebensfähige Spermien, vor Gefrieren) + $20 \mathrm{ml} \mathrm{Seminalplasma;} \mathrm{G2} \mathrm{-} \mathrm{besamt} \mathrm{mit} \mathrm{Gefriersperma} \mathrm{(800} \mathrm{x} 10^{6}$ lebensfähige Spermien, vor Gefrieren) + Kortikosteroidtherapie; G3 - besamt mit Gefriersperma (800 x $10^{6}$ lebensfähige Spermien, vor Gefrieren) + $20 \mathrm{ml}$ Seminalplasma + Kortikosteroidtherapie. Die Kortikosteroidtherapie der Stuten bestand aus der Gabe von Prednisolonacetat $(0,1$ $\mathrm{mg} / \mathrm{kg}$ - Prede ${ }^{\circledR}$ ) mit dem Auftreten $35 \mathrm{~mm}$ großer Follikel und eines intrauterinen Ödems, begleitet von einer einmaligen Gabe hCG (humanes Choriongonadotropin). Die Steroidtherapie wurde bis zur Ovulation alle 12 Stunden wiederholt. Beim ersten Versuch mit gesunden Stuten konnten keine Unterschiede in der Trächtigkeitsrate zwischen der Kontrollgruppe und der behandelten Gruppe (p>0,05) festgestellt werden. Hierbei wurden entweder Seminalplasma bzw. zusätzlich Kortikosteroide (40\% bzw. 38\%) oder Seminalplasma und ausschließlich Kortikosteroide (40\% bzw. 45\%) verwendet. Im zweiten Versuch mit Stuten, die bekanntermaßen bereits besamungsinduzierte Endometritiden aufgezeigt hatten, wurde ein signifikanter Anstieg der Trächtigkeitsrate bei den mit Kortikosteroiden behandelten Tieren $(0,0 \%$ bzw. 64\%; $p<0,05)$ dokumentiert. Es konnte festgestellt werden, dass die Kortikosteroidtherapie als ein sicheres Verfahren angesehen werden kann, ohne negativen Einfluss auf den physischen oder reproduktionsmedizinischen Status der behandelten Stuten. Weiterhin handelt es sich um eine sinnvolle Therapie für Tiere, die bekanntermaßen bereits besamungs-/bedeckungsinduzierte Endometritiden aufgewiesen haben. Es sind jedoch weitere klinische Studien nötig, um diese Ergebnisse zu bestätigen und eine präventive Therapie bei Fällen von besamungsinduzierter Endometritis zu etablieren.

Schlüsselwörter: Stute, Kortikosteroide, Seminalplasma, Gefriersperma, Fertilität, Reproduktion

\section{Introduction}

Endometritis induced after insemination is a physiological and transitory inflammation that contributes to the clearance of dead spermatozoa and other uterine contaminants brought with semen deposition (Troedsson 1999). Inflammation is caused by the presence of sperms in the uterus and is characterized by a rapid infusion of polymorphonuclear cells (PMN) beginning one hour after insemination and ending in approximately 36 hours in normal mares (Kotilainen et al.
1994, Katila 1995, Troedsson 1999, Troedsson et al. 2000, Troedsson et al. 2001). LeBlanc et al. (1989) described the mechanism of uterine clearance on the period following ovulation and affirmed that mares which are susceptible to endometritis accumulated more fluid inside the uterus after ovulation than resistant mares, demonstrating that accumulation of cellular debris and bacteria on this period may occur due to a dysfunction of normal defense mechanism of the animal. However, other authors reported that myometrial contraction (mechanic clearance) does not appear to be responsible for 
the post-ovulation inflammation and that PMN are present in the uterus after semen deposition (Brook 1985). A high number of leucocytes and frequently sperms phagocytosed by PMN have been detected in uterine washes of mares after insemination (Bader and Krause 1980). Spermatic antigenicity to the uterus is a well known event, but the real damage caused by this inflammatory response on fertility rates is still unclear. Troedsson (1999) reported that seminal plasma presents a suppressive effect on complement activity; in another study, Troedsson et al. (1998) verified that seminal plasma suppresses PMN migration in vitro.

Corticosteroids act basically on four events: altering leucocyte circulation; interfering in the mechanism of lymphocytic immunity; modulating inflammatory mediators and modifying the metabolism of proteins, carbohydrates and lipids. Frean et al. (1997), Yallampalli et al. (1994) and Alghamdi et al. (2005) affirmed that nitric oxide is an inflammatory mediator that among other effects causes smooth muscle relaxation and is synthesized by different cells (e.g. macrophages, neutrophils, epithelial cells) from L-arginin by three isoforms of $\mathrm{NO}$-synthases.

Dell'Aqua Junior et al. (2006) evaluated the modulation of uterine inflammatory response after insemination with frozen semen in mares and observed that uterine inflammation is not influenced by semen presentation - "in natura" or frozen, that seminal plasma does not interfere with the concentration of uterine neutrophils after insemination, that corticosteroid therapy decreases neutrophilic function and that IgA concentration in blood serum and uterine wash fluid is not altered by corticosteroid therapy or insemination.

The severity of post-insemination inflammatory response varies individually among animals and is less intense in those submitted to corticosteroid therapy, which does not interfere in the moment of ovulation, in the animal's physical condition and contributes to cleaner uterine washes.

The aim of the present study was to verify the effect of corticosteroid therapy on fertility rates after frozen semen insemination.

\section{Material and Methods}

\section{Semen Freezing}

After collection with artificial vagina, the ejaculates were processed as follows: filtered to remove debris; diluted in skim milk glucose extender on the proportion of $1: 1$; centrifuged at $600 \times \mathrm{g}$ for 10 minutes; resuspended in MP50 freezing extender (Papa et al. 2002), at 200x106 viable sperms $/ \mathrm{mL}$; packed in $0.5 \mathrm{~mL}$ French straws; stabilized at $5^{\circ} \mathrm{C}$ for 20 minutes; frozen in isopor box, six centimeters above nitrogen level, for 20 minutes; immersed in liquid nitrogen and stored in cryobiological container.

The quality control of semen samples used on fertility trials was performed in CERBEQ. Samples were thawed in water bath at $46^{\circ} \mathrm{C}$ for 20 seconds (Dell'Aqua Junior 2000) and sperm parameters were evaluated by CASA (Hamilton Thorne Research - IVOS 10) and fluorescent probes carboxifluo- rescein and propidium iodide, as described by Harrison and Vickers (1990) and modified by Zúccari (1998).

\section{Seminal Plasma Preparation}

Seminal plasma used at the moment of inseminations was obtained from the same stallion that donated the semen samples and was processed as follows: after semen collection by artificial vagina, the ejaculate was filtrated and centrifuged at $600 x \mathrm{~g}$ for 10 minutes to remove approximately $90 \%$ of spermatozoa (Dell'Aqua Junior 2000). The supernatant was again centrifuged at $5000 \times \mathrm{g}$ for 60 minutes at $5^{\circ} \mathrm{C}$ to completely remove the sperms. The remaining seminal plasma was divided in aliquots of $20 \mathrm{~mL}$ and stored at $-20^{\circ} \mathrm{C}$. At the moment of insemination, seminal plasma was thawed at $37^{\circ} \mathrm{C}$ for 10 minutes and deposited in the uterus with an insemination pipette and a $20 \mathrm{~mL}$ syringe immediately before insemination of frozen semen.

\section{Fertility Trial}

Fertility trial was performed in two steps, the first at CERBEQ (Center of Equine Reproduction and Biotechnology of Animal Reproduction Department) and the second at Santa Maria Farm-Itapetininga-SP.

For the first test, two cycles of 30 mares without history of fluid accumulation were used on two distinct protocols: 1 - Control $(n=15) \quad X$ corticosteroid therapy + seminal plasma $(n=15)$ (post ovulation insemination with $800 \times 10^{6}$ viable sperms pre-freezing); 2 - Control $(n=15) X$ corticosteroid therapy $(n=15)\left(400 \times 10^{6}\right.$ viable sperms pre ovulation and 400 $\times 10^{6}$ viable sperms post ovulation).

Mares were used as control of themselves on the first cycle and all inseminations were performed on uterine body. Corticosteroid therapy consisted on one administration of prednisolone acetate $\left(0.1 \mathrm{mg} / \mathrm{Kg}\right.$ - Predef $\left.{ }^{\circledR}\right)$ when mares presented $35 \mathrm{~mm}$ follicles and uterine edema, then repeated each 12 hours until ovulation and seminal plasma was used on the quantity of $20 \mathrm{~mL}$, immediately before inseminations. Mares were daily examined by rectal palpation and ultrasonography to monitor follicular growth. When follicles reached $35 \mathrm{~mm}$ and the presence of uterine edema was verified, ovulation was induced with $2500 \mathrm{IU}$ of hCG and mares from treated groups started receiving corticosteroid therapy. Pre-ovulation inseminations were performed 36 hours after hCG administration and post-ovulation inseminations were performed 48 hours after hCG. At this moment, $95 \%$ of mares had already ovulated and those which did not ovulate in this period were inseminated each 12 hours until ovulation was detected.

For the second fertility trial, only mares with previous history of post-insemination fluid accumulation were used and inseminations were performed according to the procedure adopted by the veterinarians responsible for the farm. Thirty cycles of fifteen mares were inseminated with commercial frozen semen of different stallions. On first cycle, mares were inseminated without any preventive treatment and on second cycle they were submitted to corticosteroid therapy, as described before, thus they could be used as control of themselves. 


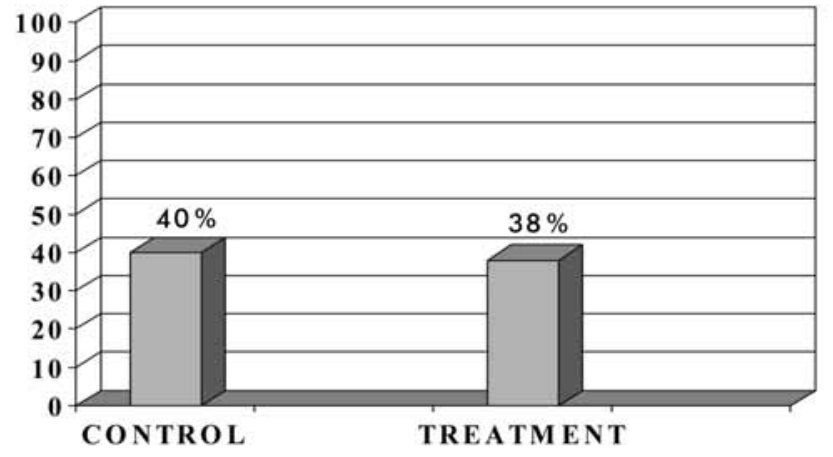

Fig 1 Percentage of pregnant mares in the control group (normal mares inseminated post-ovulation in the uterine body with $800 \times 10^{6}$ sperms before freezing) and the treatment group (normal mares inseminated post-ovulation on uterine body with $800 \times 10^{6}$ sperms before freezing $+20 \mathrm{~mL}$ seminal plasma and submitted to corticosteroid therapy), $p>0.10$.

Prozentsatz tragender Stuten aus der Kontrollgruppe (gesunde Stuten, die postovulatorisch mit $800 \times 10^{6}$ lebensfähigen Spermien (vor Gefrieren) in den Corpus uteri besamt wurden) und der behandelten Gruppe (gesunde Stuten, die postovulatorisch mit $800 \times 10^{6}$ lebensfähigen Spermien (vor Gefrieren) + 20m/ Seminalplasma unter Kortikosteroidtherapie in den Corpus uteri besamt wurden), $p>0,10$.

All mares were inseminated post-ovulation, with doses varying from 200 to $500 \times 10^{6}$ viable sperms after thawing, on the tip of uterine horn, near uterine tubal junction, using a flexible pipette $\left(\right.$ Minitub $\left.^{\circledR}\right)$. On both tests, pregnancy diagnosis was done 15 days after ovulation by ultrasonography.

\section{Statistical analysis}

Percentages of pregnant mares obtained on fertility trials were analyzed by Fisher test and differences were considered significant when $p<0.05$.

\section{Results}

Results obtained from fertility trials demonstrated that corticosteroid therapy was efficient when realized in mares with previous history of post-insemination endometritis.

In the first fertility trial, with normal mares, there was no difference between control and treated groups $(p>0.10)$, using seminal plasma associated to corticosteroid therapy (40 vs. $38 \%$, respectively) or corticosteroid therapy alone (40 vs. $45 \%$, respectively) (Figures 1 and 2).

The second fertility trial, performed at Santa Maria Farm with mares with previous history of fluid accumulation after insemination, demonstrated a significant increase of pregnancy rate when mares were submitted to corticosteroid therapy (0.0 vs. $64.5 \%$, respectively; $p<0.05)$, as shown in Figure 3 .

\section{Discussion}

Different factors may influence pregnancy rates, as the quality of semen, the technique of semen preservation, gynecological condition of mares and all the physical and biochemi-

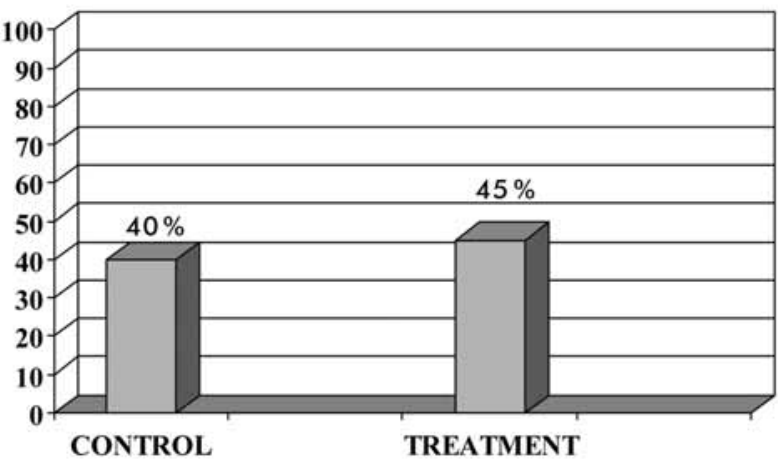

Fig 2 Percentage of pregnant mares in the control group (normal mares inseminated pre and post-ovulation in the uterine body with $400 \times 10^{6}$ sperms) and the treatment group (normal mares inseminated pre and post-ovulation in the uterine body with $400 \times 10^{6}$ sperms and submitted to corticosteroid therapy), $p>0.10$.

Prozentsatz tragender Stuten aus der Kontrollgruppe (gesunde Stuten, die prä- und postovulatorisch mit $400 \times 10^{6}$ lebensfähigen Spermien in den Corpus uteri besamt wurden) und der behandelten Gruppe (gesunde Stuten, die prä- und postovulatorisch mit $400 \times 10^{6}$ lebensfähigen Spermien unter Kortikosteroidtherapie in den Corpus uteri besamt wurden), $p>0,10$.

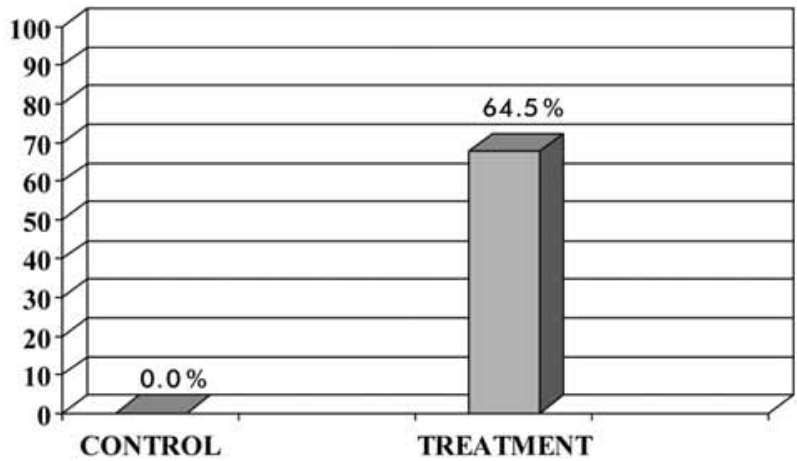

Fig 3 Percentage of pregnant mares in the control group (susceptible mares inseminated pre and post-ovulation near the uterine tubal junction with 200 to $500 \times 10^{6}$ viable sperms after freezing) and treatment group (susceptible mares inseminated pre and post-ovulation near the uterine tubal junction with 200 to $500 \times 10^{6}$ viable sperms after freezing and submitted to corticosteroid therapy), $\mathrm{p}<0.05$.

Prozentsatz tragender Stuten aus der Kontrollgruppe (anfällige Stuten, die prä- und postovulatorisch mit $200-500 \times 10^{6}$ lebensfähigen Spermien (nach Gefrieren) nahe der Uterus-Eileiter-Verbindung besamt wurden) und der behandelten Gruppe (anfällige Stuten, die prä- und postovulatorisch mit 200 - $500 \times 10^{6}$ lebensfähigen Spermien (nach Gefrieren) unter Kortikosteroidtherapie nahe der Uterus-Eileiter-Verbindung besamt wurden), $p<0,05$.

cal processes to which gametes are submitted until fertilization occurs. The intention of investigating a possible interference of uterine post-insemination inflammatory response as a deleterious factor to pregnancy rates in mares has stimulated many authors to develop research trying to obtain some answer to the cause of this inflammation and low fertility rates when frozen semen is used.

Some authors have correlated severe neutrophilic infiltration after frozen semen insemination to the presence of glycerol, egg yolk, milk and other compounds used on semen extenders (Bergman and Dekruif 1997, Parlevliet et al. 1997). Del- 
I'Aqua Junior et al. (2006), however, evaluated the modulation of uterine inflammatory response after insemination and observed that this process does not depend on semen presentation - "in natura" or frozen and that the addition of seminal plasma does not change the concentration of neutrophils inside the uterus after insemination. Troedsson et al. (1993) observed that uterine activity is higher on the first 6 hours after breeding, and is maintained until 19 hours in resistant mares, but decreases to basal levels during this period in susceptible mares. According to Frean et al. (1997), Yallampalli et al. (1994) and Alghamdi et al. (2005), the presence of nitric oxide promotes uterine relaxation and may contribute to a decrease in uterine clearance. Dell'Aqua Junior et al. (2006) observed a marked decrease on neutrophil function and on fluid accumulation, resulting in cleaner uterine washes, when susceptible mares were submitted to corticosteroid therapy during insemination protocol. The use of corticosteroid therapy as a modulator of uterine inflammatory response was shown to be a safe and efficient procedure when used in mares with previous history of post-insemination endometritis. This therapy is based on the prevention of an undesired inflammatory response, modulating immune response so that endometrial recovery may occur in time to receive an embryo on a healthy environment, thus improving fertility rates in mares susceptible to post-breeding endometritis.

\section{Acknowledgements}

This study was supported by FAPESP.

\section{References}

Alghamdi A. S., Foster D. N., Carlson C. S. and Troedsson M. H. T. (2005) Nitric oxide levels and nitric oxide synthase expression in uterine samples from mares susceptible and resistant to persistent breeding-induced endometritis. Am. J. Reprod. Immunology 53, 230-237

Bader H. and Krause (1980) A. Investigations about the transport, distribution and the fate of spermatozoa in the genital tract of the mare. 9th International Congress on Animal Reproduction \& Artificial Insemination 5, 197-200

Bergman H. J. and Dekruif A. (1997) Preliminary evaluation of the inflammatory response of the endometrium on semen, extender and its components in mares. Pferdeheilkunde 13, 543

Brook D. (1985) Cytological and bacteriological examination of the mare's endometrium. Equine Vet. Sci. 5, 16-22

Dell'Aqua Junior J. A. (2000). Efeito da centrifugação, tipos de envase e temperatura de descongelação sobre os parâmetros espermáticos e índices de fertilidade relacionados com o local de deposição do sêmen e concentração da dose inseminante de sêmen congelado eqüino. Botucatu, 2000. 81 p. Dissertação (Mestrado)- Faculdade de Medicina Veterinária e Zootecnia, Universidade Estadual Paulista.
Dell'Aqua Junior J. A., Papa F. O., Lopes M. D., Alvarenga M. A., Macedo L. P. and Melo C. M. (2006) Modulation of acute uterine inflammatory response after artificial insemination with frozen semen. Animal Reprod. Sci. 94, 270-273

Frean S. P., Bryant C. E., Frolin I. L., Elliott J. and Lees P. (1997) Nitric oxid production by equine articular cells in vitro. Equine Veterinary Journal 29, 98-102

Harrison R. A. P. and Vickers S. E. (1990). Use of fluorescent probes to assess membrane integrity in mammalian spermatozoa. J. Reprod. Fertil. 88, 343-352

Katila T. (1995) Onset and duration of uterine inflammatory response of mares after insemination with fresh semen. Biol. Reprod. (Monographs) 1, 515-517

Kotilainen T., Huhtinen M. and Katila T. (1994) Sperm-induced leukocytosis in the equine uterus. Theriogenology 41, 629-636

LeBlanc M. M., Asbury A. C. and Lyle S. K. (1989). Uterine clearance mechanisms during the early postovulatory period in mare. Am. J. Vet. Res. 6, 864-867

Papa F. O., Zahn F. S., Dell'Aqua Junior J. A. and Alvarenga M. A. (2002). Utilização do diluente MP50 para criopreservação de sêmen eqüino. Revista Brasil. Reprod. Anim. 26, 184-186

Parlevliet J. M., Tremoleda J. M., Cheng K. P., Pycock J. F. and Colenbrander B. (1997) Influence of semen, extender and seminal plasma on the defence mechanism of the mare's uterus. Pferdeheilkunde 13, 54

Troedsson M. H. T., Liu I. K. M. and Thurmond M. (1993) Function of uterine and blood-derived polymorphonuclear neutrophils in mares susceptible and resistant to chronic uterine infection. J. Reprod. Fert. 44, 283-288

Troedsson M. H. T., Liu I. K. and Crabo B. G. (1998) Sperm transport and survival in the mare: a review. Theriogenology $50,807-818$

Troedsson M. H. T. (1999). Uterine clearance and resistance to persistent endometritis in mare. Theriogenology 52, 461-471

Troedsson M. H. T., Lee C.-S., Franklin R. D. and Crabo B. G. (2000) The role of seminal plasma in post-breeding uterine inflammation. Journal of Reproduction and Fertility Suppl. 56, 341-349

Troedsson M. H. T., Loseth K., Alghamdi A. M. and Crabo B. G. (2001) Interaction between equine semen and the endometrium: the inflammatory response to semen. Proceedings, 3rd International Symposium on Stallion Reproduction, Fort Collins, Colorado, 27

Yallampalli C., Byam-Smith M., Nelson S. O. and Garfield R. E. (1994) Steroid hormones modulate the production of nitric oxide and cGMP in the rat uterus. Endocrinology 134, 1971-1974

Zuccari C. E. S. N. (1998) Efeito da criopreservação sobre a integridade estrutural da célula espermática eqüina. Botucatu, 1998, 121 p. Tese (Doutorado) - Faculdade de Medicina Veterinária e Zootecnia - Universidade Estadual Paulista "Júlio de Mesquita Filho".

Frederico Ozanam Papa

Faculdade de Medicina Veterinária e Zootecnia

Distrito de Rubião Junior $s / n$

Botucatu, SP, CEP 18618-000

Brazil.

papa@fmvz.unesp.br

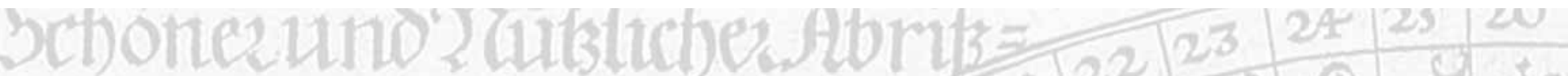 Q4 Pferdeheilkunde libri}

